Tropical Journal of Pharmaceutical Research March 2019; 18 (3): 669-676

ISSN: $1596-5996$ (print); 1596-9827 (electronic)

(C) Pharmacotherapy Group, Faculty of Pharmacy, University of Benin, Benin City, 300001 Nigeria.

Available online at http://www.tjpr.org

http://dx.doi.org/10.4314/tjpr.v18i3.30

Review Article

\title{
Medicinal uses, phytochemistry, pharmacology and toxicological properties of Elaeodendron croceum
}

\author{
Alfred Maroyi \\ Medicinal Plants and Economic Development (MPED) Research Centre, Department of Botany, University of Fort Hare, Private \\ Bag X1314, Alice 5700, South Africa
}

*For correspondence: Email: amaroyi@ufh.ac.za; Tel: +27-719600326

Sent for review: 16 November 2018

Revised accepted: 24 February 2019

\begin{abstract}
Elaeodendron croceum is a shrub or a small tree used as an emetic, purgative and herbal medicine for cough, sore throat, fever, tuberculosis, blood in sputum, chest congestion, human immunodeficiency virus (HIV) opportunistic infections and to clean the digestive tract. Phytochemical compounds identified from the species include alkaloids, cardiac glucoside, flavonoids, phenols, proanthocyanidins, saponins, sugars, tannins and triterpenoids. Pharmacological studies revealed that E. croceum extracts and compounds have antimycobacterial, anti-arthritic, antibacterial, anti-HIV, antioxidant, anti-inflammatory, antifungal and cytotoxicity activities. Future studies should focus on ethnopharmacological safety and efficacy of $E$. croceum extracts and compounds isolated from the species using in vivo preclinical studies and clinical trials.
\end{abstract}

Keywords: Celastraceae, Elaeodendron croceum, Herbal medicine, Southern Africa, Traditional medicine

This is an Open Access article that uses a funding model which does not charge readers or their institutions for access and distributed under the terms of the Creative Commons Attribution License (http://creativecommons.org/licenses/by/4.0) and the Budapest Open Access Initiative (http://www.budapestopenaccessinitiative.org/read), which permit unrestricted use, distribution, and reproduction in any medium, provided the original work is properly credited.

Tropical Journal of Pharmaceutical Research is indexed by Science Citation Index (SciSearch), Scopus, International Pharmaceutical Abstract, Chemical Abstracts, Embase, Index Copernicus, EBSCO, African Index Medicus, JournalSeek, Journal Citation Reports/Science Edition, Directory of Open Access Journals (DOAJ), African Journal Online, Bioline International, Open-J-Gate and Pharmacy Abstracts

\section{INTRODUCTION}

Elaeodendron croceum (Thunb.) DC. is a shrub or a small evergreen tree species which belongs to the Celastraceae family. The species is commonly referred to as forest saffron, saffron or wood saffron. $E$. croceum has in the past classified under several scientific names such as Cassine crocea (Thunb.) Kuntze, C. papillosa (Hochst.) Kuntze, Crocoxylon croceum Thunb. N. Robson, C. excelsum Eckl. \& Zeyh., E. capense Eckl. \& Zeyh., Salacia zeyheri Planch. ex Harv., Ilex crocea Thunb., E. croceum Thunb. DC. and E. papillosum Hochst. [1,2]. E. croceum is among the top 15 medicinal plants that are becoming scarce in KwaZulu Natal province in South Africa based on the information provided by traditional healers [3-5]. The could be as a result of overcollection as the species is widely sold in informal herbal medicine markets in both rural and urban areas of Gauteng [6] and KwaZulu Natal provinces in South Africa [4]. Overcollection of wild populations of E. croceum as a source for medicinal plant trade and other anthropogenic activities such as habitat destruction and land clearing for agricultural purposes have caused a severe reduction in the population size of the species [7]. E. croceum is regarded as Least Concern on the IUCN Red List of Threatened Species [8] but due to local 
conservation concern in South Africa as the population of the species is declining, the species has been flagged as declining following recommendations made by Williams et al [9], Von Staden et al [10] and Victor and Keith [11]. It is against this background that the medicinal uses, phytochemistry, pharmacology and toxicological properties of $E$. croceum were reviewed.

\section{METHODS}

Data on medicinal uses, botany, phytochemistry, pharmacological and toxicological properties of E. croceum were collected from multiple internet sources including Science Direct, SciFinder, Pubmed, BMC, Elsevier, Google Scholar, Scopus and Web of Science. Complementary information was gathered from pre-electronic sources such as books, book chapters, theses, scientific reports and journal articles obtained from the University library. The search for this information was carried out between May 2017 to August 2018. The keywords used in the search included "ethnobotany", "ethnomedicinal uses", "medicinal uses", "phytochemistry", "biological activities", "pharmacological properties", "toxicological properties", "Elaeodendron croceum", the synonym of the species and the English common names "forest saffron", "saffron" or "wood saffron". The internet search generated 562 articles in total. After duplicate articles and those with limited raw data were excluded, 36 articles were included in this study. These articles included 21 journal articles, books (nine), scientific report (three), websites (two) and a single book chapter.

\section{FINDINGS AND DISCUSSION}

Botanical profile and medicinal uses of $E$. croceum

E. croceum (Figure 1) grows up to a height of 15 metres with a trunk diameter of $250 \mathrm{~mm}$ [12]. The species has been recorded in montane forest margins and along the escarpment, mainly on seepage zones. The main stem is red-brown to grey in colour and may have some dark lenticels when young characterized by pale grey and thin bark, peeling off to reveal bright orange and yellow under-bark [13]. The leaves are opposite to sub-opposite in arrangement and oblong to elliptic in shape. The apex and base of the leaves is broadly tapering, leaf margins are strongly serrated and sometimes spined. The leaves are glossy green above and little paler below with prominent venation on both sides. The flowers are small, whitish or pale green in colour, occurring axillary clusters. The fruits are fleshy, ovoid in shape and creamy to yellowish in colour [14]. The species has been recorded in Mozambique, South Africa, Swaziland, Zimbabwe and naturalized in St Helena [1,14].

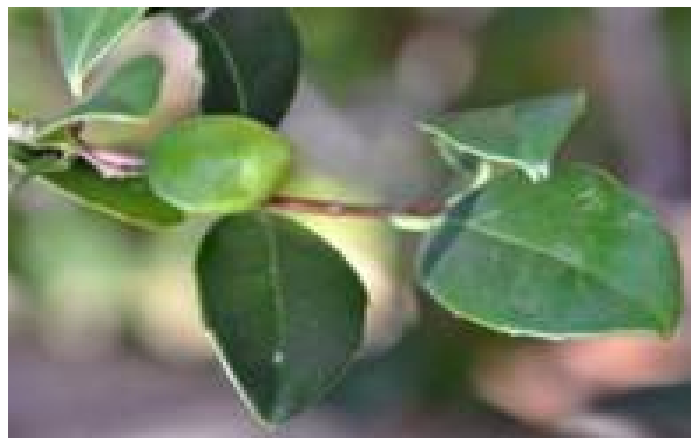

Figure 1: E. croceum branch showing a fruit and leaves (photo: D Becking)

E. croceum bark is used as an emetic and purgative $[15,16]$ as herbal medicine against human immunodeficiency virus (HIV) opportunistic infections [17]. The bark is also traditionally used to treat and manage tuberculosis [18] and other related diseases such as blood in sputum [18], chest congestion [12,16,19-21], cough [18] and sore throat [16]. The bark is used to manage and treat fever [18] and bark, roots and leaves of the species as herbal medicine to clean the digestive tract $[12,16,19-21]$.

Table 1: Medicinal uses of E. croceum

\begin{tabular}{llll}
\hline Medicinal use & P[ant part(s) used & Country & Reference(s) \\
\hline Blood in sputum & Bark infusion taken orally & South Africa & {$[18]$} \\
Chest congestion & Bark infusion taken orally & South Africa & {$[12,16,19-21]$} \\
Clean digestive tract & Bark, leaf and root infusion taken orally & South Africa & {$[12,16,19-21]$} \\
Cough & Bark decoction taken orally & South Africa & {$[18]$} \\
Emetic & Bark infusion taken orally & Swaziland & {$[15]$} \\
Fever & Bark decoction taken orally & South Africa & {$[18]$} \\
HIV & Bark decoction taken orally & South Africa & {$[17]$} \\
Purgative & Bark infusion taken orally & South Africa & {$[16]$} \\
Sore throat & Bark decoction taken orally & South Africa & {$[16]$} \\
Tuberculosis & Bark infusion taken orally & South Africa & {$[18]$} \\
\hline
\end{tabular}




\section{Phytochemistry and pharmacological properties of $E$. croceum}

Reports on the phytochemical screening of $E$. croceum leaf, root and stem bark extracts revealed the presence of alkaloids, flavonoids, phenols, proanthocyanidins, saponins and tannins [22,23]. Drewes and Mashimbye [24] isolated flavonoids, sugar and triterpenoids and these compounds included (+)-6R,13R-11,11dimethyl-1,3,8,10-tetrahydroxy-9-methoxy-

peltogynan, (-)-4'-0-methoxyepigallocatechin, ouratea proanthocyanidin A, galactitol, tingenone, tingenin $\mathrm{B}$, canophyllol, 3hydroxylupeol and 30-hydroxylup 20(29)-en-3one from the stem bark of E. croceum (Figure 2). Prinsloo et al [20] isolated a cardiac glucoside, digitoxigenin-glucoside from $E$. croceum bark extracts (Figure 2). Yelani et al [21] isolated triterpenoids such as 20-hydroxy-20epitingenone, tingenone, tingenine $B, 11 \alpha-$ hydroxy- $\beta$-amyrin and naringenin from the leaves of E. croceum (Figure 2).

Prinsloo et al [20] evaluated anti-HIV activities of the compound digitoxigenin-glucoside isolated from $E$. croceum extracts by assessing the inhibition of recombinant HIV strain in an MT-2 VSV-pseudotyped recombinant virus assay. The compound showed significant inhibition of $90 \%$ at $0.2 \mu \mathrm{M}$ [20]. Prinsloo et al $[20,25]$ evaluated the cytotoxicity of the compound digitoxigeninglucoside using the colourimetric 3-(4,5dimethylthiazol-2-yl)-2, 5-diphenyltetrazolium bromide (MTT) assay on Vero cells and scored as percentage reduction at $540 \mathrm{~nm}$ of treated culture versus untreated control culture. The isolated compound showed toxicity of only $20 \%$ at a concentration of $25 \mu \mathrm{g} / \mathrm{ml}$ on Vero cells with a therapeutic index of $250[20,25]$. Yelani et al [21] evaluated the cytotoxicity of hexane, dichloromethane, and acetone leaf extracts of $E$. croceum and compounds 20-hydroxy-20epitingenone, tingenone, tingenine $B, 11 \alpha-$ hydroxy- $\beta$-amyrin and naringenin isolated from the leaves of the species using the XTT (sodium 3'-[1-(phenyl amino-carbonyl)-3,4-tetrazolium]bis-[4-methoxy-6-nitro] benzene sulfonic acid hydrate) colorimetric assay against four human cancer cell lines, Vero (monkey kidney), HeLa (human cervix cancer), SNO (human oesophagus cancer) and MCF-7 (human breast cancer) with doxorubicin and zearalenone as positive controls. All extracts showed activities, but significant activities were demonstrated by compounds 20-hydroxy-20-epitingenone and tingenone which showed activities against Vero cells with half maximal inhibitory concentration $\left(\mathrm{IC}_{50}\right)$ values of $2.7 \mathrm{nM}$ and $8.2 \mu \mathrm{M}$, respectively. The cytotoxicity of compounds 20-hydroxy-20- epitingenone and tingenone against three human cancer cell lines, HeLa, MCF-7, and SNO showed $\mathrm{IC}_{50}$ values ranging between $2.5 \mu \mathrm{M}$ to $0.4 \mu \mathrm{M}[21]$.

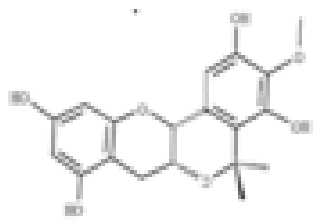

(+)-6R,13R-11,11-dimethyl1,3,8,10-tetrahydroxy-9methoxy-peltogynan

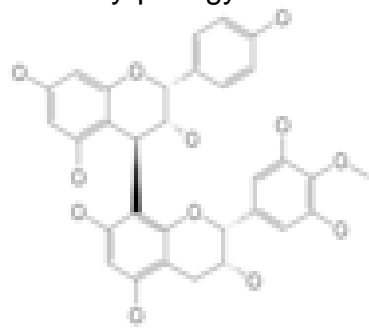

Ouratea proanthocyanidin A

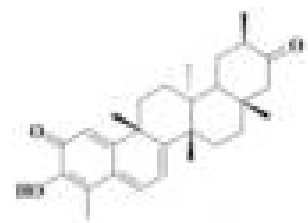

Tingenone

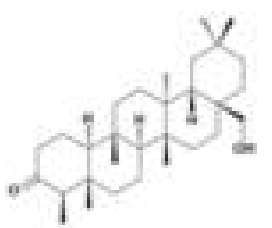

Canophyllol

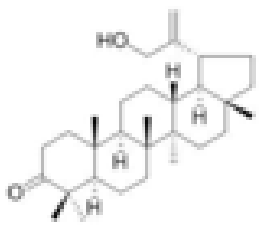

30-hydroxylup 20(29)en-3-one

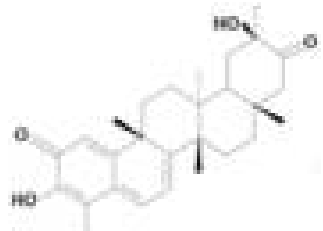

20-hydroxy-20-epitingenone

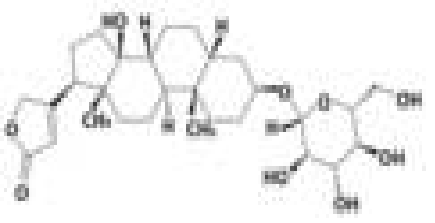

Digitoxigenin-glucoside

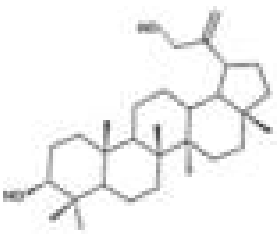

3-hydroxylupeol llocatechin

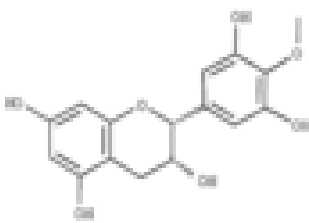

-)-4'-0-methoxyepiga-

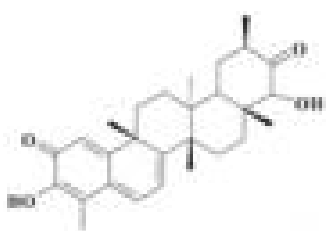

Tingenin B

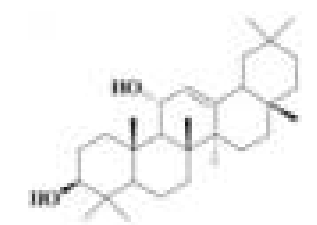

11a-hydroxy- $\beta$-amyrin

Naringenin

Figure 2: Chemical structures of compounds isolated from $E$. croceum

Trop J Pharm Res, March 2019; 18(3):671 


\section{Anti-arthritic activity}

Elisha et al [23] evaluated the anti-arthritic activities of acetone extract of $E$. croceum leaves using an anti-protein denaturation assay. The extract had a dose dependent response in the in vitro anti-arthritic test, exhibited $\mathrm{IC}_{50}$ value of 80.0 $\mu \mathrm{g} / \mathrm{ml}$ which was higher than the $I_{50}$ value of $32.4 \mu \mathrm{g} / \mathrm{ml}$ exhibited by the positive control diclofenac sodium [23]. The promising activities of the extracts support the traditional usage of the species for inflammatory conditions.

\section{Antibacterial activity}

Eloff et al [26] evaluated antibacterial activities of acetone extract of $E$. croceum bark using the agar diffusion method against Staphylococcus aureus, Enterococcus faecalis, Escherichia coli and Pseudomonas aeruginosa. The extract showed activities against the tested pathogens with total activity values ranging from $8.0 \mathrm{ml} / \mathrm{g}$ to $>275.0 \mathrm{ml} / \mathrm{g}$ [26]. Kaikabo et al [27] evaluated antibacterial activities of acetone extract of $E$. croceum bark using a two-fold serial microdilution method against Staphylococcus aureus, Enterococcus faecalis, Escherichia coli and Pseudomonas aeruginosa. The minimum inhibitory concentrations (MIC) screening was conducted at concentrations of $0.02 \mathrm{mg} / \mathrm{ml}$ to 2.5 $\mathrm{mg} / \mathrm{ml}$. The extracts had activity against at least one of the test organisms over a period of 1,2 or 24 hours with average MIC values of the extracts against the tested pathogens ranging from 0.2 $\mathrm{mg} / \mathrm{ml}$ to $1.8 \mathrm{mg} / \mathrm{ml}$ [27].

Elisha et al [28] evaluated antibacterial activities of acetone extract of $E$. croceum leaves against Bacillus anthracis Sterne strain using the microplate serial dilution method with gentamicin as a positive control. The extract showed activities with MIC value of $0.3 \mathrm{mg} / \mathrm{ml}$ and total antibacterial activity of $290.0 \mathrm{ml} / \mathrm{g}$ [28]. Elisha et al [29] evaluated the antibacterial activities of acetone extract of $E$. croceum leaves against Stenotrophomonas maltophilia, Klebsiella pneumoniae, Salmonella typhimurium, Proteus mirabilis, Enterobacter cloacae and Escherichia coli using a serial microdilution method with gentamicin as a positive control. The extract exhibited activities with MIC values ranging from $0.08 \mathrm{mg} / \mathrm{ml}$ to $0.31 \mathrm{mg} / \mathrm{ml}$ and total antibacterial activity values ranging from $290.2 \mathrm{ml} / \mathrm{g}$ to 1124.6 $\mathrm{ml} / \mathrm{g}$ [29].

Elisha et al [30] evaluated antibacterial activities of acetone extract of $E$. croceum leaves against Escherichia coli, Staphylococcus aureus, Enterococcus faecalis, Bacillus cereus, Salmonella typhimurium and Pseudomonas aeruginosa using microplate serial dilution technique with gentamicin as a positive control. The extract showed activities with MIC values ranging from $0.08 \mathrm{mg} / \mathrm{ml}$ to $0.4 \mathrm{mg} / \mathrm{ml}$ and total antibacterial activity ranging from $214.2 \mathrm{ml} / \mathrm{g}$ to $1124.6 \mathrm{ml} / \mathrm{g}$ [30]. Mamba et al [17] evaluated antibacterial activities of ethanol extract of $E$. croceum bark against Gardnerella vaginalis, Neisseria gonorrhoeae and Oligella ureolytica using the broth microdilution method with ciprofloxacin as a positive control. The extract exhibited activities against tested pathogens with MIC values ranging from $1.6 \mathrm{mg} / \mathrm{ml}$ to $12.5 \mathrm{mg} / \mathrm{ml}$ while ciprofloxacin exhibited MIC value of $<0.01 \mathrm{mg} / \mathrm{ml}$ [17]. Odeyemi and Afolayan [24] evaluated antibacterial activities of aqueous extract of $E$. croceum leaves and stem bark against Enterococcus faecalis, Klebsiella pneumoniae, Proteus vulgaris, Salmonella typhimurium, Shigella flexneri and Staphylococcus aureus using the agar well diffusion and broth microdilution methods with amoxicillin (0.0125 $\mathrm{mg} / \mathrm{mL}$ ) as the positive control. The extracts exhibited activities against all the tested pathogens with zone on inhibition ranging from $13.0 \mathrm{~mm}$ to $15.7 \mathrm{~mm}$. The control, amoxicillin was active against Enterococcus faecalis, Klebsiella pneumoniae, Shigella flexneri and Staphylococcus aureus with zone on inhibition ranging from $12.5 \mathrm{~mm}$ to $26.5 \mathrm{~mm}$. The MIC values exhibited by the extracts and the control against all the pathogens ranged from $0.6 \mathrm{mg} / \mathrm{ml}$ to $>5.0 \mathrm{mg} / \mathrm{ml}$ [24]. The documented antibacterial activities exhibited by $E$. croceum extracts show the potential of the species as herbal medicine against bacterial pathogens and also corroborate the traditional uses of the species as herbal medicine against sore throat in South Africa [16].

\section{Antimycobacterial activity}

Lall and Meyer [18] evaluated antimycobacterial activities of aqueous and acetone extracts of $E$. croceium bark against drug-resistant and drugsensitive strains of Mycobacterium tuberculosis H37Rv using the agar plate method. The acetone extract exhibited activities with MIC value of 1.0 $\mathrm{mg} / \mathrm{ml}$ [18]. Elisha et al [31] evaluated the antimycobacterial activities of acetone extract of E. croceum leaves against Mycobacterium aurum, Mycobacterium fortuitum and Mycobacterium smegmatis using serial microdilution method with rifampicin and streptomycin as positive controls. The extracts showed activities against tested pathogens with MIC value of $1.3 \mathrm{mg} / \mathrm{ml}$ against Mycobacterium fortuitum and MIC value of $2.5 \mathrm{mg} / \mathrm{ml}$ against both Mycobacterium aurum and Mycobacterium smegmatis and total antimycobacterial activities ranged from $36.0 \mathrm{ml} / \mathrm{g}$ to $72.0 \mathrm{ml} / \mathrm{g}$. The positive 
controls, rifampicin and streptomycin showed MIC values ranging from $0.01 \mathrm{mg} / \mathrm{ml}$ to 0.06 $\mathrm{mg} / \mathrm{ml}$ [31]. These findings corroborate the traditional uses of the species as herbal medicine against tuberculosis [18] and related diseases such as blood in sputum [18], chest congestion $[12,16,19-21]$, cough [18] and sore throat [16].

\section{Antifungal activity}

Mamba et al [17] evaluated antifungal activities of ethanol extract of $E$. croceum bark against Candida albicans using the broth microdilution method with ciprofloxacin as a positive control. The extract exhibited activities with MIC value of $1.6 \mathrm{mg} / \mathrm{ml}$ while ciprofloxacin exhibited MIC value of $<0.01 \mathrm{mg} / \mathrm{ml}$ [17]. The documented antifungal activities exhibited by $E$. croceum extracts show the potential of the species as herbal medicine against fungal and microbial pathogens.

\section{Anti-HIV activity}

Prinsloo et al [23] evaluated anti-HIV activities of E. croceum by assessing inhibition of transcription factors in the HeLa-TAT-Luc and MT-2 VSV-pseudotyped recombinant virus assays. The extracts showed potent inhibition of transcription factors at $100 \mathrm{ng} / \mathrm{mL}$ [23]. Mamba et al [17] evaluated anti-HIV activities of ethanol extract of $E$. croceum bark against recombinant HIV-1 enzyme using non-radioactive HIV-reverse transcriptase (RT) colorimetric assay with doxorubicin as a positive control. The extract exhibited low inhibitory activity of $30.2 \%$ while the positive control doxorubicin showed 96.5\% inhibitory activity [17]. The documented anti-HIV activities exhibited by $E$. croceum extracts and the compound digitoxigenin-glucoside isolated from the species corroborate the traditional usage of the species against HIV opportunistic infections in South Africa [17].

\section{Anti-inflammatory activity}

Elisha et al [25] evaluated the anti-inflammatory activities of acetone extract of $E$. croceum leaves by determining the inhibition of nitric oxide production in lipopolysaccharide activated RAW 264.7 macrophages as well as 15-lipoxygenase enzyme inhibition. The extracts inhibited nitric oxide production in a dose-dependent manner in the LPS-stimulated RAW 264.7 macrophages with $E$. croceum inhibiting $\mathrm{NO}$ production by 71.1 $\%$ at a concentration of $30.0 \mu \mathrm{g} / \mathrm{ml}$. The extract exhibited good activities against 15-lipoxygenase activity with $\mathrm{IC}_{50}$ value of $26.2 \mu \mathrm{g} / \mathrm{ml}$ which was better than $\mathrm{IC}_{50}$ value of $53.7 \mu \mathrm{g} / \mathrm{ml}$ exhibited by the positive control quercetin [25].
Mamba et al [17] evaluated anti-inflammatory activities of ethanol extract of E. croceum bark by assessing the inhibitory effects on the proinflammatory enzyme, 15-lipoxygenase (15-LOX) with quercetin as a positive control. The extract exhibited activities with $\mathrm{IC}_{50}$ values of $80.2 \mu \mathrm{g} / \mathrm{ml}$ while quercetin, the positive control exhibited $\mathrm{IC}_{50}$ value of $48.9 \mu \mathrm{g} / \mathrm{ml}$ [17]. Odeyemi and Afolayan [24] evaluated anti-inflammatory activities of acetone extracts of $E$. croceum leaf and stem bark using the protein denaturation assay with diclofenac as a positive control. The extracts showed activities with leaf and stem bark extracts exhibiting $I_{50}$ values of $0.9 \mathrm{mg} / \mathrm{ml}$ and $1.9 \mathrm{mg} / \mathrm{ml}$, respectively while diclofenac, the positive control exhibited $\mathrm{IC}_{50}$ value of $0.3 \mathrm{mg} / \mathrm{ml}$ [24]. Olaokun et al [32] evaluated the antiinflammatory activities of acetone extracts of $E$. croceum bark by assessing the inhibitory effects on the pro-inflammatory enzyme, 5-lipoxygenase (5-LOX) with quercetin as a positive control. The extract inhibited the activity of 5-lipoxygenase with an $\mathrm{IC}_{50}$ value $75.5 \mu \mathrm{g} / \mathrm{ml}$ [32]. These finding show the potential of $E$. croceum as herbal medicine for inflammatory conditions, pain and wounds.

\section{Antioxidant activity}

Elisha et al [25] evaluated the antioxidant activities of acetone extract of $E$. croceum leaves using the 2,2-dipheny-l-picrylhydrazyl (DPPH) free radical scavenging, 2,2'-azinobis-3ethylbenzothiazoline-6-sulphonate (ABTS), ferric reducing power (FRAP) and the trolox equivalent antioxidant capacity (TEAC) assays with ascorbic acid and trolox as reference drugs. The extracts showed good ABTS and DPPH activities with $\mathrm{IC}_{50}$ values of $3.1 \mu \mathrm{g} / \mathrm{mL}$ and $7.7 \mu \mathrm{g} / \mathrm{mL}$, respectively, which were comparable to $\mathrm{IC}_{50}$ values ranging from $2.9 \mu \mathrm{g} / \mathrm{mL}$ to $5.6 \mu \mathrm{g} / \mathrm{mL}$ exhibited by ascorbic acid and trolox, the two positive controls. FRAP and TEAC values were 1.0 and 1.3, respectively while ascorbic acid and trolox showed values ranging from 1.0 to 3.7 [25].

Odeyemi and Afolayan [24] evaluated antioxidant activities of acetone extracts of $E$. croceum leaf and stem bark using the DPPH free radical scavenging, ABTS and FRAP assays with ascorbic acid, butylated hydroxytoluene (BHT) and rutin as reference drugs. The leaf extract $\mathrm{IC}_{50}$ values for ABTS assay was $0.09 \mathrm{mg} / \mathrm{ml}$, DPPH $(0.1 \mathrm{mg} / \mathrm{ml})$ and FRAP $(2.5 \mathrm{mg} / \mathrm{ml})$ while bark extract $\mathrm{IC}_{50}$ values for ABTS assay was 0.2 $\mathrm{mg} / \mathrm{ml}$, DPPH $(0.07 \mathrm{mg} / \mathrm{ml})$ and FRAP $(9.2$ $\mathrm{mg} / \mathrm{ml})$. The $I_{50}$ values exhibited by the reference drugs, ascorbic acid, BHT and rutin ranged from $0.02 \mathrm{mg} / \mathrm{ml}$ to $3.5 \mathrm{mg} / \mathrm{ml}$ [24]. The 
documented antioxidant activities of the extracts of $E$. croceum are probably a result of flavonoids and phenolics which have been isolated from the species [24,25].

\section{Cytotoxic activity}

Prinsloo et al [20,23] evaluated the cytotoxicity of semi-purified stem bark extracts of $E$. croceum using the colorimetric MTT assay on Vero cells and scored as percentage reduction at $540 \mathrm{~nm}$ of treated culture versus untreated control culture. The extract showed toxicity of only $20 \%$ at a concentration of $25 \mu \mathrm{g} / \mathrm{ml}$ on Vero cells with a therapeutic index of 250 [20,23]. Elisha et al [28] evaluated cytotoxicity activities of acetone extract of $E$. croceum leaves on Vero monkey kidney cells using the MTT reduction assay with doxorubicin as a positive control. The extract showed activities with median lethal concentration $\left(\mathrm{LC}_{50}\right)$ value of $5.2 \mu \mathrm{g} / \mathrm{ml}$ and selectivity index (SI) value of 0.02 while doxorubicin, the positive control showed $\mathrm{LC}_{50}$ value of $8.3 \mu \mathrm{g} / \mathrm{ml}$ [28].

Elisha et al [30] evaluated cytotoxic activities of acetone extract of $E$. croceum leaves using MTT reduction assay on Vero cells. The extract showed activities with $\mathrm{LC}_{50}$ value of $5.2 \mu \mathrm{g} / \mathrm{ml}$ and selectivity index (SI) value ranging from 0.01 to 0.07 while doxorubicin, the positive control showed $\mathrm{LC}_{50}$ value of $8.3 \mu \mathrm{g} / \mathrm{ml}$ [30]. The extract exhibited high cytotoxicity, supporting findings by Yelani et al [21] who argued that cytotoxicity of $E$. croceum on Vero cells is due to toxic triterpenoids 20-hydroxy-20-epitingenone, tingenone, tingenine $B$, 11hydroxy-amyrin and naringenin isolated from the leaves of the species.

Despite the long use of E. croceum as herbal medicine in South Africa and Swaziland to treat numerous human diseases, the roots of the species are reported to have been used to cause death by traditional healers [33,34]. Research by Kunene et al [35] showed that E. croceum is categorized as detrimental and causing death of cattle in KwaZulu Natal province, South Africa. Experiments upon rabbits found that $2.5 \mathrm{~g}$ per $\mathrm{kg}$ body weight, and $10 \mathrm{~g}$ of fresh leaves per $\mathrm{kg}$ body weight caused death fifteen minutes after administration [36]. Based on these toxicological reports, it can be inferred that $E$. croceum should be taken with caution when used as herbal medicine.

\section{FINAL REMARKS}

Pharmacological studies carried out so far showed that the different extracts and constituents of the species to be promising, which calls for detailed phytochemical, pharmacological and clinical studies of different extracts and chemical constituents of the species. Determination of the active principles is very important in the extracts and compounds of the species in order to avoid life-threatening complications as the species is widely used as herbal medicine. There is lack of information about the effect of prolonged consumption of $E$. croceum extracts. Therefore, future studies should include the identification of toxic compounds, possible side effects caused by taking $E$. croceum as herbal medicine, and mechanisms of how potential toxic components of the species can be managed.

\section{DECLARATIONS}

\section{Acknowledgement}

Financial support of this work by the National Research Foundation (NRF) and Govan Mbeki Research and Development Centre (GMRDC), University of Fort Hare is gratefully acknowledged.

\section{Conflict of Interest}

No conflict of interest associated with this work.

\section{Contribution of Authors}

The authors declare that this work was done by the authors named in this article and all liabilities pertaining to claims relating to the content of this article will be borne by them.

\section{REFERENCES}

1. Archer RH, Van Wyk AE. A taxonomic revision of Elaeodendron Jacq. (Cassinoideae: Celastraceae) in Africa. S Afr J Boty 1998; 64: 93-109.

2. Germishuizen G, Meyer NL. Plants of southern Africa: an annotated checklist. Strelitzia 14. National Botanical Institute, Pretoria; 2003; $p 1238$.

3. Cunningham $A B$. An investigation of the herbal medicine trade in Natal/KwaZulu. Investigational Report Number 29. Institute of Natural Resources, Pietermaritzburg; 1988. $149 p$.

4. Cunningham AB. African medicinal plants: setting priorities at the interface between conservation and primary health care. People and Plants Working Paper 1, UNESCO, Paris; 1993. 53 p.

5. Mander M. Marketing of medicinal plants in South Africa: a case study in KwaZulu-Natal. Food and Agriculture Organization of the United Nations, Rome; 1998. 151 p. 
6. Williams VL, Balkwill K, Witkowski ETF. A lexicon of plants traded in the Witwatersrand umuthi shops, South Africa. Bothalia 2001; 31(1): 71-98.

7. Raimondo $D$, von Staden L, Foden W, Victor JE, Helme $N A$, Turner RC, Kamundi DA, Manyama PA. Red list of South African plants. Strelitzia 25. South African National Biodiversity Institute, Pretoria; 2009. 668 p.

8. International Union for Conservation of Nature (IUCN). IUCN Red List Categories and Criteria. Version 3.1. Gland; 2012. Available on: http://www.iucnredlist.org/ technical-documents/categories-and-criteria, retrived 11 June 2018.

9. Williams VL, Victor JE, Crouch NR. Red Listed medicinal plants of South Africa: status, trends, and assessment challenges. S Afr J Bot 2013; 86: 23-35.

10. von Staden $L$, Raimondo $D$, Foden $W$. Red list of South African plants. In: Raimondo $D$, von Staden $L$, Foden $W$, Victor JE, Helme NA, Turner RC, Kamundi DA, Manyama $P A$, editors. Approach to red list assessments. Pretoria: Strelitzia 25, South African National Biodiversity Institute; 2009. p. 6-16.

11. Victor JE, Keith $M$. The Orange list: a safety net for biodiversity in South Africa. S Afr J Sci 2004; 100: 139141.

12. Schmidt E, Lotter M, McCleland W. Trees and shrubs of Mpumalanga and Kruger National Park. Jacana Media, Johannesburg; 2002. 702 p.

13. Palgrave MC. Keith Coates Palgrave trees of southern Africa. Struik Publishers, Cape Town, 2002; 1212 p.

14. Van Wyk B, Van Wyk P. Field guide to trees of southern Africa. Struik, Cape Town; 1997; $536 p$.

15. Long C. Swaziland's flora: siSwati names and uses. Swaziland National Trust Commission, Mbambane; 2005. Available on: http://www .sntc.org.sz/index.asp, retrieved on 4 February 2018.

16. van Wyk B-E, Van Oudtshoorn B, Gericke N. Medicinal plants of South Africa. Briza Publications, Pretoria; 2013. $336 p$

17. Mamba P, Adebayo SA, Tshikalange TE. Anti-microbial, anti-inflammatory and HIV-1 reverse transcriptase activity of selected South African plants used to treat sexually transmitted diseases. Int $J$ Pharmacog Phytochem Res 2016; 8(11): 1870-6.

18. Lall N, Meyer JJM. In vitro inhibition of drug-resistant and drug-sensitive strains of Mycobacterium tuberculosis by ethnobotanically selected South African plants. J Ethnopharmacol 1999; 66: 347-54.

19. Pujol J. NaturAfrica the herbalist handbook: African flora, medicinal plants. Natural Healers Foundation, Durban; 1990. $415 p$

20. Prinsloo G, Meyer JJM, Hussein AA, Munoz E, Sanchez R. A cardiac glucoside with in vitro anti-HIV activity isolated from Elaeodendron croceum. Nat Prod Res 2010; 24: 1743-6.

21. Yelani $T$, Hussein AA, Meyer JJM. Isolation and identification of poisonous triterpenoids from Elaeodendron croceum. Nat Prod Res 2010; 24: 141825.
22. Odeyemi SW, Afolayan AJ. 2017. Biological activities and phytochemical screening of Elaeodendron croceum (Thunb.) DC. leaves and stem barks extracts. Int $\mathrm{J}$ Phytomed 2017; 9(4): 566-575.

23. Elisha IL, Dzoyem J-P, McGaw LJ, Botha FS, Eloff JN. The anti-arthritic, anti-inflammatory, antioxidant activity and relationships with total phenolics and total flavonoids of nine South African plants used traditionally to treat arthritis. BMC Complem Altern Med 2016; 16: 307.

24. Drewes SE, Mashimbye MJ: Flavanoids and triterpenoids from Cassine papillosa and the absolute configuration of 11,11-dimethyl-1,3,8,10-tetrahydroxyl-9mathoxypeltogynan. Phytochem 1993; 32(4): 1041-4.

25. Prinsloo G, Meyer JJM, Hussein AA. Anti-HIV activity of a cardiac glycoside isolated from Elaeodendron croceum. S Afr J Bot 2011; 111: 308.

26. Eloff JN. On expressing the antibacterial activity of plant extracts: a small first step in applying scientific knowledge to rural primary health care. South African $J$ Science 2000; 96(3): 116-118.

27. Kaikabo AA, Suleiman MM, Samuel BB, Eloff JN. Antibacterial activity of eleven South African plants use in treatment of diarrhoea in folkloric medicine. $J$ Trad Complem Altern Med 2008; 5: 315-6.

28. Elisha IL, Dzoyem J-P, Botha FS, Eloff JN. The efficacy and safety of nine South African medicinal plants in controlling Bacillus anthracis Sterne vaccine strain. BMC Complem Altern Med 2016; 16: 5.

29. Elisha IL, Jambalang AR, Botha FS, Buys EM, McGaw $L J$, Eloff JN. Potency and selectivity indices of acetone leaf extracts of nine selected South African trees against six opportunistic Enterobacteriaceae isolates from commercial chicken eggs. BMC Complem Altern Med 2017; 17: 90

30. Elisha IL, Botha FS, McGaw LJ, Eloff JN. The antibacterial activity of extracts of nine plant species with good activity against Escherichia coli against five other bacteria and cytotoxicity of extracts. Complem Altern Med 2017; 17: 133.

31. Elisha IL, Botha FS, Madikizela B, McGaw LJ, Eloff JN. Acetone leaf extracts of some South African trees with high activity against Escherichia coli also have good antimycobacterial activity and selectivity index. BMC Complem Altern Med 2017; 17: 327.

32. Olaokun OO, Mkolo NM, King PH. Inhibition of 5lipoxygenase and phytochemical content of five South African medicinal plants. S Afr J Bot 2018; 115: 326-7.

33. Watt JM, Breyer-Brandwijk MG. The medicinal and poisonous plants of Southern and East Africa. E \& S Livingstone Ltd, Edinburgh, 1962. 1457 p.

34. Palmer E, Pitman P. Trees for southern Africa covering all known indigenous species in Republic of South Africa, South West Africa, Botswana, Lesotho and Swaziland. Cape Town: AA Balkema; 1972. 792 p.

35. Kunene N, Wilson RAC, Myeni NP. The use of trees, shrubs and herbs in livestock production by communal 
farmers in northern KwaZulu-Natal, South Africa. Afr J Range Forage Sci 2003; 20(3): 271-4.
36. Steyn DG. The toxicology of plants in South Africa. Onder $J$ Vet Sci Animal Ind 1934; 3(2): 359-416. 